Journal of Engineering and Applied Sciences 7 (1): 90-99, 2012

ISSN: 1816-949X

(C) Medwell Journals, 2012

\title{
Dual Fueling of a Twin-Cylinder Compression Ignition Engine with Diesel and CNG
}

\author{
Ranbir Singh and Sagar Maji \\ Department of Mechanical Engineering, Delhi Technological University, \\ Bawana Road, 110042 Delhi, India
}

\begin{abstract}
This study presents a detailed experimental research carried out on a twin-cylinder, four-stroke direct injection compression ignition engine converted to operate on dual fuel mode using Compressed Natural Gas $(\mathrm{CNG})$ as the primary fuel. A venturi mixer is designed by developing a computer program in EES (Engineering equation solver) Software and then fabricated for mixing proper amount of CNG with air before admission to engine cylinder. Data for analysis of performance parameters such as brake thermal efficiency and brake specific fuel consumption was recorded both for straight diesel and dual fuel modes of operations. Engine running cost analysis was carried out on the basis of fuel consumption cost for $1 \mathrm{~h}$ of continuous operation of diesel engine at a particular load for both the modes. Experimental results indicate that with an increase in CNG substitution rate, brake thermal efficiency of CNG-diesel dual fuel engine is low at low loads but it is remarkably high at higher engine loads. Brake specific fuel consumption for dual fuel mode is better than pure diesel mode as the rate of CNG substitution was increased. The cost of fuel for running a CNG-diesel dual fuel engine is found less than that for pure diesel engine as the CNG substitution rate increases. In this study, $90 \%$ saving in consumption of conventional diesel fuel is achieved by its replacement with cheap and abundantly available CNG fuel.
\end{abstract}

Key words: Brake thermal efficiency, $\mathrm{CNG}$, diesel, dual fuel mode, engine running cost analysis, venturi mixer

\section{INTRODUCTION}

Compressed natural gas is considered a viable alternate fuel in view of its high energy content, low cost and abundant availability. It defuses in air fuel mixing at lower inlet temperature than is possible with either gasoline or diesel. This allows easier starting, more reliable idling, smoother acceleration and more complete and efficient burning with less unburned hydrocarbons present in the exhaust.

CNG has high octane no. (130) as compared to that of gasoline (87) allows a higher CR (15.6:1) and consequently more efficient fuel consumption. Due to higher $\mathrm{CR}$, diesel engines can efficiently use $\mathrm{CNG}$ as an alternate fuel. But cetane rating of CNG is poor, it cannot replace diesel totally like gasoline (Kirti et al., 2005). It has wide flammability range, capability to form homogeneous airfuel mixtures, low photochemical reactivity and lower global toxicity of exhaust gases with use in diesel engines (Corbo et al., 1995). CNG has been used in SI engines in recent years because of its relatively high octane number and lower exhaust emissions. In these engines, $\mathrm{CNG}$-air homogeneous mixture is supplied in gaseous state which reduces their induction volume efficiency. CNG SI engines may therefore have $15 \%$ lower maximum power output than that of gasoline engines. The $\mathrm{CR}$ of this type of engines can not be made as high as that of diesel engines because of the occurrence of knock. As a result, thermal efficiency of spark ignited natural gas engines is inferior to that of conventional diesel engines. There have been reports of engine overheating with CNG SI engines because they operate close to the stoichiometric gas/air ratio which results in higher peak local temperatures. This also increases the chances of dissociation reactions for forming $\mathrm{NO}_{\mathrm{z}}$ and often results in incomplete combustion (Kusaka et al., 2002).

Diesel engines have high thermal efficiency and they are expected to remain the dominant heavy duty transport power plant in the future also. To keep the benefits of diesel engines is the main objective of researchers and their manufacturers (Song and Hill, 1985). So, the use of $\mathrm{CNG}$ in $\mathrm{CI}$ engines seems to be a very good option as an alternative fuel for relieving dependency on petroleum based conventional diesel fuel as the depletion rate of diesel fuel is about 4 times than that of petrol.

To overcome the shortcomings of CNG SI engines and to utilize full potential of $\mathrm{CNG}$, a new combustion system using $\mathrm{CNG}$ as a dual fuel in existing diesel engines has been proposed in recent years. In this system, knocking can be avoided because the homogeneous CNG-air mixture is prepared by the use of a gas mixer installed in the intake system before it is introduced into

Corresponding Author: Ranbir Singh, Delhi College of Engineering, Delhi, India 


\section{J. Eng. Applied Sci., 7 (1): 90-99, 2012}

the cylinder. The mixture is then ignited by a very small amount of piloted diesel fuel which is injected into the cylinder by way of a multi-spray injector. Thus, many flame kernels are provided based on the ignition of diesel sprays. This prevents engine from knocking and allows a high compression ratio comparable to that of conventional diesel engines.

Karim (1983) reviewed the prospects, problems and solutions of the dual fuel engine and shown that it is a very attractive mode for use of gaseous fuel at high efficiencies and output. Karim (1991) examined some measures for improving the performance of gas fuelled diesel engine at light load and found poor fuel utilization efficiency at light load. Recommended that at idling and very light load condition, straight diesel operation should be resorted to. Doughty et al. (1992) studied dual fuel engine with methane content of $94.30 \%$ by volume in natural gas and found that for full load operation, the fuel efficiency was similar to diesel operation. For lower loads, the fuel efficiency was decreased for fixed pilot injection timing. Hountalas and Papagiannakis (2000) studied dual diesel-NG engine with use of a mixture of methane $=90 \%$ and propane $=10 \%$ as primary fuel and concluded that dual fuel operation results in higher combustion pressures. Singh et al. (2004) studied the combustion and emissions of a diesel-NG dual fuel engine and shown that its combustion and emissions are well predicted.

Ahmad et al. (2005) studied different parameters affecting the performance of a CNG-diesel dual fuel engine and found that with an increase in percentage of $\mathrm{CNG}$ substitution the brake power decreases, the exhaust gas temperature and peak cylinder pressure also decreases. An improvement in brake specific energy consumption is observed compared to pure diesel mode. Saraf et al. (2008) reviewed the Diesel-CNG dual fuel technology and observed that torque and power obtained at different engine speeds on dual fuel mode were slightly more than diesel mode. Most of these experimental studies were carried out on single cylinder direct injection diesel engines. There are very few studies on multi-cylinder engines converted to operate on dual fuel mode such as those of Ahmad et al. (2005) and Egusquiza et al. (2009) which are available in the literature. Moreover, the CNG composition in India is different in its other cities and in other countries. Therefore, the extents to which the findings of the above studies apply to other types of multi-cylinder diesel engines and composition of $\mathrm{CNG}$ available in Delhi need further experimental studies on dual fuel mode of operation. The objective of the present research study is intended to modify the existing conventional CI engine and study the effect of substituting diesel by $\mathrm{CNG}$ and to analyse the engine performance characteristics of a Direct Injection (DI), twin cylinder diesel engine for straight diesel and CNG-diesel dual fuel modes at different engine loads for various percentage substitution rates of CNG up to engine knock free power output. The engine running cost analysis is also carried out on the basis of fuel consumption cost for $1 \mathrm{~h}$ of continuous operation of diesel engine at a particular load for both the modes. The results for straight diesel mode and CNG-diesel dual fuel modes are represented graphically for analysis.

\section{MATERIALS AND METHODS}

Conversion of conventional diesel engine: Conversion of a conventional diesel engine to dual fuel (CNG-diesel) and dedicated CNG engine both is practically possible.

Conversion to CNG dedicated: The conventional diesel engine is converted in such a way that it uses $100 \% \mathrm{CNG}$ and need major modifications in the existing engine for combustion of CNG. The main modifications required are replacement of the injection system with spark plug and an injector pump, reduction in compression ratio to $10-12$, mounting of an ignition system with distributer, ignition coil, electric supply (alternator), etc. So, conversion of a conventional diesel engine to dedicated natural gas state requires complex modifications in the engine structure.

Conversion to dual fuel (CNG-diesel): Dual fuel engine is a conventional diesel engine which burn either gaseous fuel or diesel or both at the same time. The mode of operation is defined as straight diesel if only diesel fuel is used and dual fuel if two fuels are used at the same time. In CNG-diesel dual fuel engine, $\mathrm{CNG}$ is mixed with air at lean gas air ratios and this mixture is then compressed during the compression stroke. Near the end of compression stroke small amount of diesel fuel is injected which first auto ignites and then initiates the combustion of the CNG-air mixture. Because of its function to initiate the combustion, the diesel in dual fuel operation is often referred to as pilot diesel. The changeover of the mode of operation either from dual fuel to straight diesel or straight diesel to dual fuel can take place while the engine operates. Moreover, due to the partial replacement of liquid fuel with gaseous fuel no specific modifications are required and thus the Dual Fuel Technique can be applied to existing compression ignition engines. Therefore by conversion of a diesel engine to dual fuel mode, the desirable characteristics of efficiency and dependability normally associated with diesel engines are retained. There are some more advantages of conversion of diesel engine to dual fuel engine as its conversion is more 
economical than dedicated, higher resistance to knock; increased power output and flexibility of its conversion back to $100 \%$ diesel operation easily as the compression ratio remains unchanged. It is more environmental-friendly as it produces less hazardous emissions such as $\mathrm{CO}, \mathrm{NO}_{\mathrm{x}}$, $\mathrm{SO}_{2}$ and particulate matter.

However, there are some disadvantages associated with dual fuel which include fuel control system more complicated, difficulty in adjustment of mixing ratio of CNG-diesel, increased weight of the vehicle as dual fuel vehicle need separate tanks for storing $\mathrm{CNG}$, limited storage space and posing other drivability problems. In spite of these limitations, CNG-diesel dual fuel mode is one of the best and promising methods of utilization of cheap, clean and abundantly available $\mathrm{CNG}$ in existing diesel engines and need further research in this area.

CNG composition and properties: The exact composition of natural gas depends on whether the gas is sourced from an oil condensate field, i.e., whether it is associated gas or it exists by itself which is referred to as non associated gas. Associated gas may contain significant amounts of heavier hydrocarbons such as ethane, propane and butane together with lighter liquids such as pentane and hexane. In this category, methane percentage can be as low as $50 \%$. Non-associated gas contains a much higher percentage of methane. Table 1 shows the composition of pipeline quality natural gas supplied in India (Maji, 2002).

So, it is very important to know the composition of CNG for this study because different composition has different effects on the combustion process in the diesel engine. Since, the proportion of methane in $\mathrm{CNG}$ is the largest as compared to other gases like propane and ethane, the main characteristics of $\mathrm{CNG}$ can be directly related to the characteristics of methane. Physically, CNG is colorless, tasteless, relatively non-toxic and not a volatile organic compound. For utilization of $\mathrm{CNG}$ in internal combustion engines it has to be compressed at a high pressure of about 18-20 MPa at normal temperature in vessels before it can be supplied to the engine combustion chamber.

CNG is lighter than air with a vapor density of 0.68 relative to air. This is advantageous because if leaking happens, it will not cause explosion but instead it will disperse to the atmosphere. It has high auto-ignition temperature compared to gasoline or diesel which means that it is more difficult to ignite. This property of $\mathrm{CNG}$ is very useful for dual fuel engine application in the sense that it will reduce fire hazard and exhibit very high anti knock ability. Main properties of $\mathrm{CNG}$ and diesel are shown in Table 2 (Li, 2004).
Table 1: Typical pipeline quality natural gas in India

\begin{tabular}{lccc} 
Constituent & $\begin{array}{c}\text { Source 1 } \\
\text { (Mole \%) } \\
\text { Ex HBJ (Delhi) }\end{array}$ & $\begin{array}{c}\text { Source 2 } \\
\text { (Mole \%) } \\
\text { Ex HBJ (IPCL) }\end{array}$ & $\begin{array}{c}\text { Source 3 } \\
\text { (Mole \%) } \\
\text { Ex Mumbai }\end{array}$ \\
\hline Methane $\left(\mathrm{CH}_{4}\right)$ & 84.50 & 88.42 & 82.55 \\
Ethane $\left(\mathrm{C}_{2} \mathrm{H}_{6}\right)$ & 07.70 & 08.79 & 07.67 \\
Propane $\left(\mathrm{C}_{3} \mathrm{H}_{8}\right)$ & 02.40 & 01.59 & 03.85 \\
I-Butane $\left(\mathrm{i}-\mathrm{C}_{4} \mathrm{H}_{10}\right)$ & 0.26 & 0.29 & 0.64 \\
N-Butane $\left(\mathrm{n}^{-} \mathrm{C}_{4} \mathrm{H}_{10}\right)$ & 0.32 & 0.28 & 0.78 \\
I-Pentane $\left(\mathrm{i}-\mathrm{C}_{5} \mathrm{H}_{12}\right)$ & 0.18 & 0.05 & 0.13 \\
N-Pentane $\left(\mathrm{n}_{-}-\mathrm{C}_{5} \mathrm{H}_{12}\right)$ & 0.19 & 0.05 & 0.13 \\
Hexane $\left(\mathrm{C}_{6} \mathrm{H}_{14}\right)$ & 0.17 & 0.04 & 0.09 \\
Nitrogen $\left(\mathrm{N}_{2}\right)$ & 0.12 & 0.20 & 0.07 \\
Carbon dioxide $\left(\mathrm{CO}_{2}\right)$ & 4.23 & 0.27 & 0.07 \\
\hline
\end{tabular}

Table 2: Properties of CNG and diesel fuels

\begin{tabular}{lll}
\hline Properties & CNG & Diesel \\
\hline State & Gas & Liquid \\
Boiling point (K at 1atmos) & 147 & $433-655$ \\
Density $\left(\mathrm{kg} \mathrm{m}^{-3}\right)$ & 128 & $785-881$ \\
Auto-Ignition temperaturer $(\mathrm{K})$ & 905 & $477-533$ \\
Flash point (K) & 124 & 325 \\
Research octane number & 130 & N/A \\
Flammability limits range & $5.0-15$ & $0.7-5$ \\
Net energy content $\left(\mathrm{MJ} \mathrm{kg}^{-1}\right)$ & 49.5 & 43.9 \\
Combustion energy $\left(\mathrm{KJ} \mathrm{m}^{-3}\right)$ & 24.6 & 36 \\
Vaporization energy $\left(\mathrm{MJ} \mathrm{m}^{-3}\right)$ & $215-276$ & 192 \\
\hline
\end{tabular}

Table 3: Test engine specifications

\begin{tabular}{ll}
\hline Engine types & Kirloskar engine (AV2) \\
\hline No. of cylinders & 02 \\
No. of strokes & 04 \\
Bore & $80 \mathrm{~mm}$ \\
Stroke & $110 \mathrm{~mm}$ \\
Engine speed & $1500 \mathrm{RPM}$ \\
Rated power & $7.35 \mathrm{KW} 1500 \mathrm{RPM}$ \\
Lubricating oil & SAE 30W40 \\
\hline
\end{tabular}

Design and development of experimental test facilities: A twin-cylinder, four-stoke, direct injection, water cooled diesel engine installed at researchers IC Engine Laboratory whose technical specifications are shown in Table 3 has been converted into dual fuel engine by carrying out minor modifications which include design and fabrication of venturi, electronic speed control, rack limiter and linear load valve. The CNG-air mixer comprise of the venturimeter and the metering device which are fitted to the intake air manifold for controlling the Air-CNG mixture.

Design of venturi for CNG-air mixing: For proper mixing of air and $\mathrm{CNG}$, a venturi has been designed for various CNG-air mixture ratios. The fuel-air mixing is very important in dual fuel engine as it will provide a combustible mixture in the proper quantity and quality for efficient operation of the converted engine under all operating conditions. A computer program was developed in EES (Engineering Equation Solver) software for computing the design data of this venturi for mixing any percentage of CNG with air for any size of engine. A sample of design parameters of the venturi for $0-100 \%$ 
Table 4: Design data of venturi to mix CNG and air

\begin{tabular}{|c|c|c|c|c|c|c|c|c|c|c|}
\hline Ycng (\%) & D1 (mm) & $\mathrm{D} 2(\mathrm{~mm})$ & D3 (mm) & $\mathrm{A} 2\left(\mathrm{~m}^{2}\right)$ & $\mathrm{L} 1(\mathrm{~mm})$ & $\mathrm{L} 2(\mathrm{~mm})$ & $\mathrm{L} 3(\mathrm{~mm})$ & $\mathrm{TL}(\mathrm{mm})$ & $\mathrm{M}_{\mathrm{CNG}}\left(\mathrm{kg} \mathrm{sec}^{-1}\right)$ & $\mathrm{P} 2(\mathrm{~atm})$ \\
\hline$\overline{00}$ & 43 & 20 & 0.04765 & 314.3 & 81.83 & 2.048 & 19.92 & 103.8 & 0.0000000 & 0.894 \\
\hline 05 & 43 & 20 & 1.46300 & 314.3 & 81.83 & 3.463 & 19.92 & 105.2 & 0.0006225 & 0.894 \\
\hline 10 & 43 & 20 & 2.06800 & 314.3 & 81.83 & 4.068 & 19.92 & 105.8 & 0.0012450 & 0.894 \\
\hline 20 & 43 & 20 & 2.92500 & 314.3 & 81.83 & 4.925 & 19.92 & 106.7 & 0.0024900 & 0.894 \\
\hline 30 & 43 & 20 & 3.55300 & 314.3 & 81.83 & 5.583 & 19.92 & 107.3 & 0.0037350 & 0.894 \\
\hline 40 & 43 & 20 & 4.13700 & 314.3 & 81.83 & 6.137 & 19.92 & 107.9 & 0.0049800 & 0.894 \\
\hline 50 & 43 & 20 & 4.62500 & 314.3 & 81.83 & 6.625 & 19.92 & 108.4 & 0.0062250 & 0.894 \\
\hline 60 & 43 & 20 & 5.06700 & 314.3 & 81.83 & 7.067 & 19.92 & 108.8 & 0.0074700 & 0.894 \\
\hline 70 & 43 & 20 & 5.47200 & 314.3 & 81.83 & 7.472 & 19.92 & 109.2 & 0.0087150 & 0.894 \\
\hline 80 & 43 & 20 & 5.85000 & 314.3 & 81.83 & 7.850 & 19.92 & 109.6 & 0.0099600 & 0.894 \\
\hline 90 & 43 & 20 & 6.20500 & 314.3 & 81.83 & 8.205 & 19.92 & 110.0 & 0.0112000 & 0.894 \\
\hline 95 & 43 & 20 & 6.37500 & 314.3 & 81.83 & 8.375 & 19.92 & 110.1 & 0.0118300 & 0.894 \\
\hline 100 & 43 & 20 & 6.54100 & 314.3 & 81.83 & 8.541 & 19.92 & 110.3 & 0.0012450 & 0.894 \\
\hline
\end{tabular}

$\mathrm{P} 1=0.9 \mathrm{~atm} ; \mathrm{T} 1=300 \mathrm{~K} ; \mathrm{P} 3=1 \mathrm{~atm} ;$ Angle of convergence of venture $=8 \mathrm{deg}$; Angle of divergence $=38 \mathrm{deg}$; Bore $=80 \mathrm{~mm} ; \mathrm{Stroke}=110 \mathrm{~mm} ; \mathrm{RPM}$ $=1500$; No. of cylinders $=02$; Mass flow of air $=0.01245 \mathrm{~kg} \mathrm{sec}^{-1}$

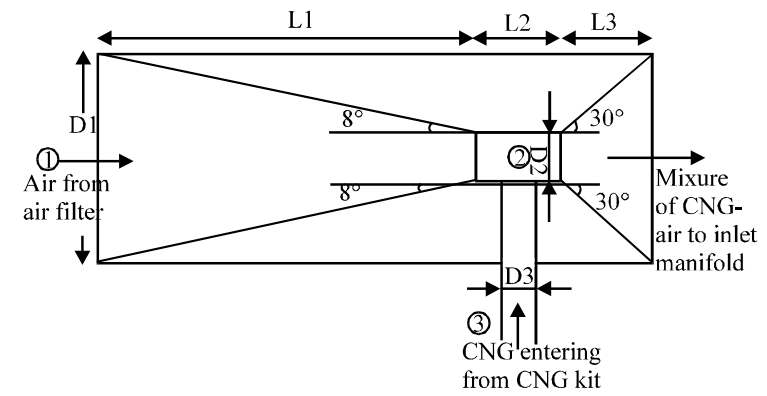

Fig. 1: Schematic drawing of deigned venturi for mixing $\mathrm{CNG}$ and air $(\mathrm{L} 1=81.83 \mathrm{~mm}, \mathrm{~L} 2=8.541 \mathrm{~mm}, \mathrm{~L} 3=$ $19.92 \mathrm{~mm}, \mathrm{D} 1=43 \mathrm{~mm}, \mathrm{D} 2=20 \mathrm{~mm}, \mathrm{D} 3=6.541 \mathrm{~mm}$, Angle of convergence $=8$ deg., Angle of divergence $=30 \mathrm{deg}$.)

CNG percentages to be mixed with air is shown in Table 4. For $100 \% \mathrm{CNG}$, the maximum diameter of the pipe through which CNG will be supplied to venturi, D3 $=6.541 \mathrm{~mm}$ and maximum length of throat, $\mathrm{L} 2=8.541 \mathrm{~mm}$ and maximum length of venturi, $T_{L}=110.3 \mathrm{~mm}$. The schematic drawing of designed venturi is shown in Fig. 1.

The following equations were formulated (Arora, 2010) assuming isentropic compressible fluid flow and small pressure drop at throat section for design of the venturi:

$$
\mathrm{V}_{\mathrm{s}}=\eta_{\mathrm{vol}} \cdot \mathrm{V}_{\mathrm{in}} \cdot \operatorname{RPM} \frac{02}{120}
$$

Where:

$\mathrm{V}_{\mathrm{s}} \quad$ = Engine swept volume per second

$\eta_{\text {vol }}=$ Volumetric efficiency of the engine

$\mathrm{V}_{\text {in }}=$ Volume of 01 cylinder of the engine

$\mathrm{RPM}=$ Revolution per minute of engine crankshaft

Assuming, velocity of air at inlet to venturi, $\mathrm{V} 1=0$ then mass flow rate of air is:

$$
\mathrm{M}_{\text {air }}=\frac{\mathrm{A} 2 \cdot \mathrm{P} 1}{\mathrm{R} .(\mathrm{T})^{0.5}} \cdot\left[2 \mathrm{Cp} \cdot\left\{\left(\frac{\mathrm{P} 2}{\mathrm{P} 1}\right)^{\frac{2}{\mathrm{k}}}-\left(\frac{\mathrm{P} 2}{\mathrm{P} 1}\right)^{1+\frac{1}{\mathrm{k}}}\right\}\right]^{0.5}
$$

Where:

$M_{\text {air }}=$ Mass flow rate of air in $\mathrm{kg} \mathrm{sec}^{-1}$

$\mathrm{A} 2=$ Area of cross section at point 2 of venture

$\mathrm{P} 1=$ Pressure of air at entry to venturi, i.e., at point 1

$\mathrm{T} 1=$ Temperature of air at inlet to venturi

$\mathrm{k}=$ Specific heat ratio of air for adiabatic process

$\mathrm{Cp}=$ Specific heat of air at constant pressure in $\mathrm{kJ}$ $\mathrm{kg}^{-1} \mathrm{~K}$

$$
\mathrm{M}_{\mathrm{CNG}}=\pi(\mathrm{D} 3)^{2}\{2 . \mathrm{pCNG}(\mathrm{P} 3-\mathrm{P} 2)\}^{0.5}
$$

Where:

$\mathrm{M}_{\mathrm{CNG}}=$ Mass flow rate of $\mathrm{CNG}$ in $\mathrm{kg} \mathrm{sec}^{-1}$

D3 = Diameter at point $3 \mathrm{in} \mathrm{mm}$

$\rho_{\mathrm{CNG}}=$ Density of CNG in $\mathrm{kg} \mathrm{cu} \mathrm{m}^{-1}$

$\mathrm{P3}=$ Pressure of CNG in Pa after CNG kit

$\mathrm{P} 2$ = Pressure at throat of venturi

$$
\mathrm{L} 1=\frac{\mathrm{D} 1-\mathrm{D} 2}{2 \cdot \tan \theta 1}
$$

Where:

$\mathrm{L} 1=$ Length of venture before throat in $\mathrm{mm}$

$\mathrm{D} 1=$ Diameter of pipe at entry to venturi in $\mathrm{mm}$

D2 $=$ Diameter of throat section in $\mathrm{mm}$

$\theta 1=$ Angle of convergence

$$
\mathrm{L} 2=\mathrm{D} 3+2
$$

Where:

D3 $=$ Diameter at point $3 \mathrm{~mm}$

$\mathrm{L} 2$ = Length of throat in $\mathrm{mm}$

$$
\mathrm{L} 3=\frac{\mathrm{D} 1-\mathrm{D} 2}{2 \cdot \tan \theta 2}
$$

Where:

L3 = Length of venturi after throat in $\mathrm{mm}$

$\theta 2=$ Angle of divergence 


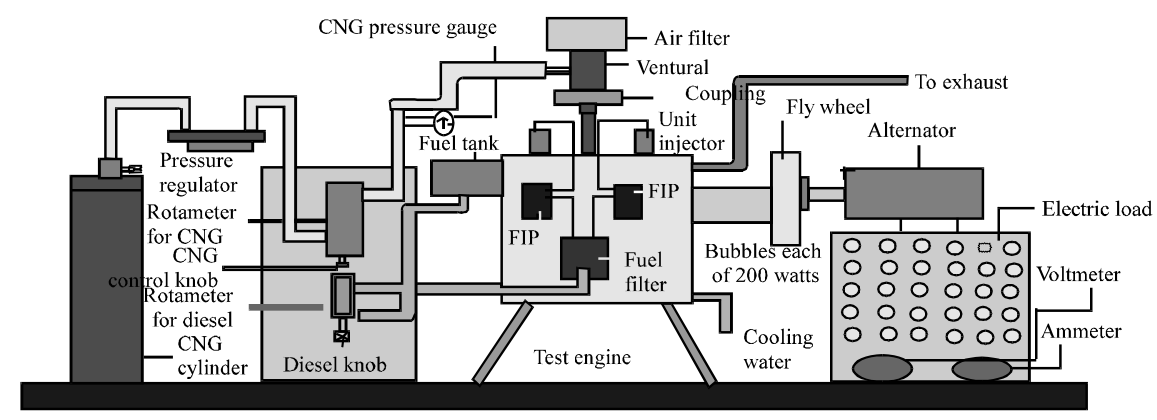

Fig. 2: Schematic diagram of developed experimental test set up

In this study, the Inlet diameter, D1, throat diameter D2 were initially assumed and the values of diameter D3, lengths L1-L3 and total length of venturi were computed by using developed computer software and assuming isentropic compressible flow analysis.

Development of experimental test set up: The venturi is fabricated using mild steel. For attachment of the venturi at the inlet pipe, a coupling has been designed and fabricated. To avoid leakage through coupling a rubber seal is used. For attaching venturi with pressure regulator, a nozzle is designed and fabricated. CNG-kit consists of a CNG storage cylinder and pressure regulator. $\mathrm{CNG}$ is stored at a working pressure of 200 bars in the cylinder. The cylinder is fitted with a shut-off value and a safety burst disc.

Pressure regulator is the heart of $\mathrm{CNG}$ conversion kit. It provides the dual fuel engine with $\mathrm{CNG}$ fuel at a constant operating pressure even if the $\mathrm{CNG}$ storage pressure varies. The main function of a gas pressure regulator is to reduce high-pressure gas in a cylinder or process line to a low pressure or usable level as it passes to another piece of equipment. CNG cylinder is attached to pressure regulator and pressure regulator is attached to nozzle at venturi by a rubber pipe of 01 inch internal diameter. For measurement of $\mathrm{CNG}$ flow rate, a rotameter is mounted in the outlet line of pressure regulator as shown in Fig. 2.

A pressure gauge is also attached in the flow line for measuring the outlet pressure of CNG. An actual image of the test engine which is converted to operate on dual fuel mode is shown in Fig. 3.

The other ancillary instruments/components that were used are: battery, ammeter, voltmeter, alternator, load panel, rotameter, high pressure piping, valves and tachometer. The engine coolant temperature was controlled to $75^{\circ} \mathrm{C}$ and lubricating oil temperature to $85^{\circ} \mathrm{C}$.

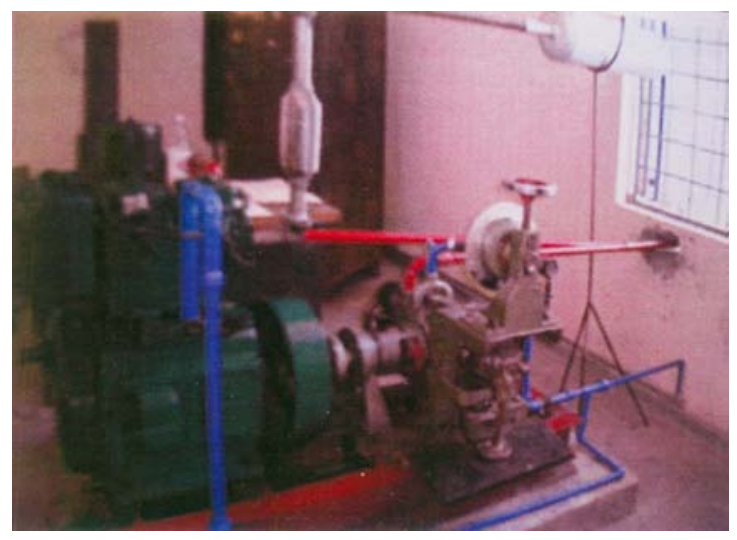

Fig. 3: Actual image of converted diesel engine

Fuels used: The CNG fuel used during this study was taken from the IGL supply station in Delhi and diesel fuel was taken from local service station in Delhi.

Performance analysis of straight diesel and CNG-diesel dual fuel engine: For measuring the performance of converted dual fuel engine experiments were conducted by changing CNG substitution rate from $0-90 \%$ and load varied from $0-7.2 \mathrm{~kW}$.

At a particular CNG substitution rate, the load is applied by electric dynamometer by switching $\mathrm{ON}$ a row of bulbs and corresponding to this CNG rate, diesel flow rate, voltage and current are measured using rotameter, voltmeter and ammeter, respectively. For taking other set of readings at this CNG substitution rate, the load is increased by switching $\mathrm{ON}$ the next row of bulbs and the observations are recorded up to $7.2 \mathrm{~kW}$ load. Again the $\mathrm{CNG}$ rate is changed and this way the whole procedure is repeated. About 42 sets of different readings were taken using various combinations of different variables. For computing the percentages of diesel fuel to CNG substitution, the Eq. 7 and 8 were used by Egusquiza et al. (2009): 


$$
\begin{gathered}
\mathrm{SR}_{\mathrm{SD} / \mathrm{CNG}}=\left[1-\left\{\frac{\mathrm{MDF}}{\mathrm{MSD}}\right\}\right. \\
\mathrm{SR}_{\mathrm{CNG}}=1-\mathrm{SR}_{\mathrm{SD} / \mathrm{CNG}}
\end{gathered}
$$

where, $M_{D F}$ and $M_{S D}$ represent the diesel fuel mass flow rate in dual fuel and straight diesel modes, respectively. Straight diesel mode is represented by $\mathrm{SR}_{\mathrm{SD} / \mathrm{CNG}}=0$ and dual fuel mode by $\mathrm{SR}_{\mathrm{SD} / \mathrm{CNG}}>0$.

Brake thermal efficiency and brake specific fuel consumption analysis: In the performance analysis of straight diesel and dual fuel modes of operation, Eq. 1-4 were formulated on the basis of thermodynamic analysis and used for computing brake thermal efficiency and brake specific fuel consumption and are represented as Eq. 9-12:

$$
\eta_{\mathrm{SD}}=\frac{(\text { V.I.PF }) \mathrm{SD}}{(\mathrm{dfr} \times \text { Density } \times \text { C.V. }) \mathrm{SD}}
$$

Where:

$$
\begin{aligned}
& \eta_{\mathrm{SD}}=\text { Thermal efficiency of straight diesel engine in } \\
& \eta_{\text {Dual }}=\frac{(\text { V.I.PF }) \mathrm{SD}}{\{(\mathrm{dfr} \times \text { Density } \times \text { C.V. }) \mathrm{SD}+} \\
& (\mathrm{dfr} \times \text { Density } \times \text { C.V.)Dual }\}
\end{aligned}
$$

Where:

$\eta_{\text {Dual }}=$ Thermal efficiency of engine in dual fuel mode in percentage

cfr $\quad=$ CNG flow rate in $\mathrm{L} \mathrm{min}^{-1}$

$\mathrm{CV}_{\text {Dual }}=$ Lower Calorific Value of CNG fuel in $\mathrm{MJ} \mathrm{kg}^{-1}$

$$
\text { bsfc }_{\mathrm{SD}}=\frac{(\mathrm{dfr} \times \text { Density } \times 60)}{(\text { V.I.PF }) \mathrm{SD}}
$$

where, $\operatorname{bsfc}_{\mathrm{SD}}$ is brake specific fuel consumption of engine in straight diesel mode and expressed as $\mathrm{g} \mathrm{kWh}^{-1}$.

$$
\mathrm{bsfc}_{\text {Dual }}=\frac{\{(\mathrm{dfr} \times \text { Density } \times 60) \mathrm{SD}+(\mathrm{cfr} \times \text { Density } \times 60) \text { Dual }\}}{\text { (V.I.PF }) \text { Dual }}
$$

where, bsfc $_{\text {Dual }}$ is brake specific fuel consumption of dual fuel engine expressed as $\mathrm{g} \mathrm{kWh}{ }^{-1}$. For a particular set of reading, CNG flow rate (cfr) is kept constant and load applied is varied from no load to $1.2,2.4,3.6,4.8,6.0$ and $7.2 \mathrm{~kW}$ and observations recorded for diesel mode and dual fuel modes separately at 1,500 RPM.

\section{RESULTS AND DISCUSSION}

The results of brake thermal efficiency, brake specific fuel consumption and engine running cost for diesel and dual fuel modes were obtained by performing experiments and computed by developing a computer software program in Engineering Equation Solver software. A sample of partial results is shown in Table 5 for straight diesel mode and Table 6 for dual fuel mode. These results under straight diesel mode and dual fuel mode of operation are compared and analyzed by representing them graphically.

CNG flow rate: The 70\%, Energy content of CNG: 17028 Watt, Cost price of diesel: Rs. $41.27 \mathrm{~L}^{-1}$, Cost price of CNG: Rs. $29.80 \mathrm{~kg}^{-1}$.

Brake thermal efficiency analysis: Figure 4 shows the variation of brake thermal efficiency with load applied for straight diesel and dual fuel modes for $\mathrm{CNG}$ substitution rates of 40,50 and $60 \%$. At CNG rate of $40 \%$ brake thermal efficiency of dual fuel engine is lower than that of straight diesel from no load to about $4.8 \mathrm{~kW}$ and it becomes more than straight diesel mode after this load. As the $\mathrm{CNG}$ rate is increased to $50 \%$, BTE of dual fuel engine also increases and it crosses the straight diesel thermal efficiency line. Same is the case with $60 \% \mathrm{CNG}$ rate. As the load on the engine is further increased it again becomes slightly lesser than straight diesel mode for $\mathrm{CNG}$ rate of $40 \%$. Its value for $\mathrm{CNG}$ rate of 50 and $60 \%$ is remarkably higher than straight diesel mode up to full engine load. This increase in brake thermal efficiency of dual fuel engine is due to better combustion efficiency and thus more amount of heat release from the combustion of CNG fuel. Figure 5 shows the comparison of brake thermal efficiency between diesel engine and dual fuel engine at CNG rates of 70,80 and $90 \%$. It is clear from Fig. 5 that at low loads thermal efficiency of straight diesel is higher than that of dual fuel engine for these CNG rates and this may be due to slow rate of combustion of $\mathrm{CNG}$ at low load operation. But as the load on the engine is increased brake thermal efficiency of dual fuel engine sharply increases and crosses straight diesel efficiency curve at a load of $4.4 \mathrm{~kW}$ for $70 \%$ and at $5.4 \mathrm{~kW}$ for $80 \%$ $\mathrm{CNG}$ rates, respectively. After these loads BTE of dual fuel mode increases sharply with increase in load for 
Table 5: A Sample of partial experimental results of straight diesel mode

\begin{tabular}{|c|c|c|c|c|c|c|c|c|c|}
\hline $\begin{array}{l}\text { Load applied } \\
\text { (kW) }\end{array}$ & $\begin{array}{l}\text { Diesel flow rate } \\
\left.(\mathrm{mL} \mathrm{min})^{-1}\right)\end{array}$ & $\begin{array}{l}\text { Voltage } \\
\text { (V) }\end{array}$ & $\begin{array}{c}\text { Current } \\
\text { amperes (I) }\end{array}$ & $\begin{array}{c}\text { Output } \\
\text { energy (Watt) }\end{array}$ & $\begin{array}{l}\text { Energy content } \\
\text { of diesel (Watt) }\end{array}$ & $\begin{array}{c}\eta_{\text {themmalSD }} \\
(\%)\end{array}$ & $\begin{array}{c}\mathrm{bsfc}_{\mathrm{SD}} \\
\left(\mathrm{gkWh}^{-1}\right)\end{array}$ & $\begin{array}{l}\text { Running cost, } \\
\mathrm{RC}_{\mathrm{SD}} \text { (Rs.) }\end{array}$ & $\begin{array}{c}\text { Volume of diesel } \\
\text { consumed (L) }\end{array}$ \\
\hline 1.2 & 28 & 210 & 05 & 840 & 15365 & 5.467 & 1500.0 & 69.33 & 1.68 \\
\hline 2.4 & 32 & 215 & 09 & 1548 & 17560 & 8.815 & 930.2 & 79.24 & 1.92 \\
\hline 3.6 & 36 & 220 & 13 & 2288 & 19755 & 11.580 & 708.0 & 89.14 & 2.16 \\
\hline 4.8 & 41 & 215 & 17 & 2924 & 22499 & 13.000 & 631.0 & 101.50 & 2.46 \\
\hline 6.0 & 46 & 215 & 22 & 3784 & 25243 & 14.990 & 547.0 & 113.90 & 2.76 \\
\hline 7.2 & 51 & 210 & 25 & 4200 & 27986 & 15.010 & 546.4 & 126.30 & 3.06 \\
\hline
\end{tabular}

Table 6: A sample of partial experimental results of dual fuel mode

\begin{tabular}{|c|c|c|c|c|c|c|c|c|c|c|c|c|}
\hline $\begin{array}{l}\text { Load } \\
\text { applied } \\
\text { (kW) }\end{array}$ & $\begin{array}{c}\text { Diesel } \\
\text { flow rate } \\
\left(\mathrm{mL} \mathrm{min}^{-1}\right)\end{array}$ & $\begin{array}{l}\text { Voltage } \\
\text { (V) }\end{array}$ & $\begin{array}{c}\text { Current, } \\
\text { amperes (I) }\end{array}$ & $\begin{array}{c}\text { Output } \\
\text { energy (W) }\end{array}$ & $\begin{array}{l}\text { Diesel } \\
\text { energy } \\
\text { content }(W)\end{array}$ & $\begin{array}{l}\text { Net } \\
\text { input } \\
\text { energy (W) }\end{array}$ & $\begin{array}{c}\eta_{\text {thermal dual }} \\
(\%)\end{array}$ & $\begin{array}{c}\mathrm{bsfc}_{\text {dual }} \\
\left(\mathrm{gm} \mathrm{kWh} \mathrm{kW}^{-1}\right)\end{array}$ & $\begin{array}{l}\text { Volume of } \\
\text { diesel } \\
\text { consumed (L) }\end{array}$ & $\begin{array}{r}\mathrm{RC}_{\mathrm{SD}} \\
\text { (Rs.) }\end{array}$ & $\begin{array}{r}\mathrm{RC}_{\text {dual }} \\
\text { (Rs.) }\end{array}$ & $\begin{array}{l}\mathrm{RC}_{\mathrm{CNG}} \\
\text { (Rs.) }\end{array}$ \\
\hline 1.2 & 11 & 215 & 05 & 860 & 6036 & 23064 & 3.73 & 575.6 & 0.66 & 27.24 & 80.88 & 53.64 \\
\hline 2.4 & 12.5 & 220 & 09 & 1584 & 6859 & 23887 & 6.63 & 355.1 & 0.75 & 30.95 & 84.59 & 53.64 \\
\hline 3.6 & 13 & 220 & 13 & 2288 & 7134 & 24162 & 9.47 & 255.7 & 0.78 & 32.19 & 85.83 & 53.64 \\
\hline 4.8 & 14 & 220 & 17 & 2992 & 7683 & 24711 & 12.11 & 210.6 & 0.84 & 34.67 & 88.31 & 53.64 \\
\hline 6.0 & 15 & 220 & 22 & 3872 & 8231 & 25259 & 15.33 & 174.3 & 0.90 & 37.14 & 90.78 & 53.64 \\
\hline 7.2 & 17 & 220 & 25 & 4400 & 9329 & 26357 & 16.69 & 173.9 & 1.02 & 42.10 & 95.74 & 53.64 \\
\hline
\end{tabular}

CNG flow rate: $70 \%$; Energy content of CNG: 17028 Watt; Cost price of diesel: Rs. $41.27 \mathrm{~L}^{-1}$; Cost price of CNG: Rs. $29.80 \mathrm{~kg}^{-1}$

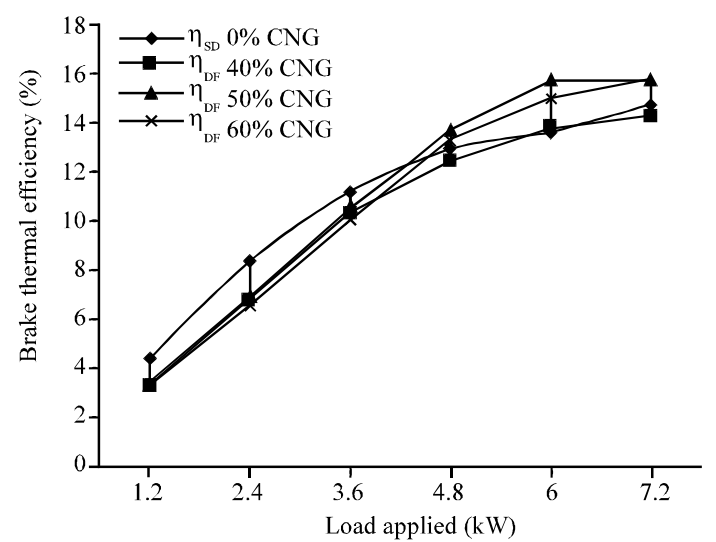

Fig. 4: Brake thermal efficiency of pure diesel and dual fuel modes at CNG substitution rates of 40,50 and $60 \%$

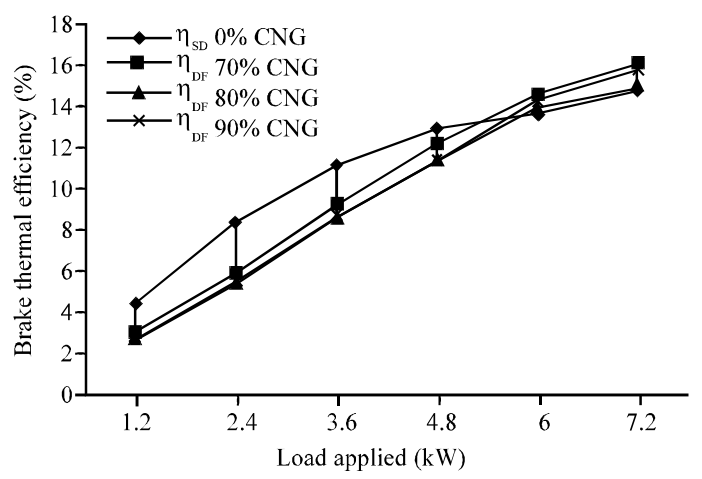

Fig. 5: Brake thermal efficiency of straight diesel and dual fuel modes at $\mathrm{CNG}$ substitution rates of 70,80 and $90 \%$

these $\mathrm{CNG}$ rates and it touches the $15.76 \mathrm{~kW}$ mark at a load of $7.2 \mathrm{~kW}$. It is seen that at higher loads and high CNG substitution rates thermal efficiency of dual fuel engine improves and it is higher than that of straight

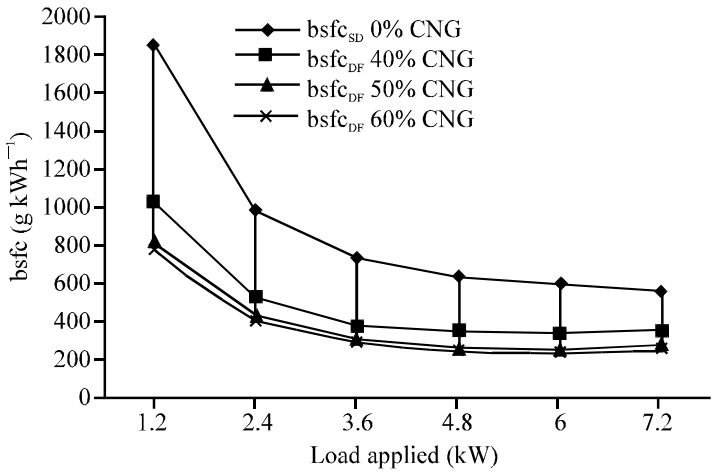

Fig. 6: Brake specific fuel consumption of straight dual fuel modes at CNG substitution rates of 40,50 and $60 \%$

diesel mode for all these three CNG rates of 70,80 and $90 \%$ upto full engine load and this may be due to proper fuel utilization and complete combustion of $\mathrm{CNG}$ at higher loads and high substitution rates of $\mathrm{CNG}$.

Brake specific fuel consumption analysis: Brake specific fuel consumption of an engine is defined as amount of fuel consumed per unit of power developed per hour. It is a clear indication of the efficiency with which the engine develops power from fuel supplied.

Figure 6 shows the variation of bsfc between straight diesel and dual fuel modes at CNG rates of 40,50 and $60 \%$. From this graph it is observed that bsfc of dual fuel engine is far less than that of straight diesel at all loads of engine operations and it is least for CNG rate of $60 \%$ from no load to full engine load. bsfc for dual mode further decreases as the CNG rate is increased from $40-60 \%$. This decrease in bsfc of dual fuel engine is a good result in favor of dual fuelling of existing diesel engines. This is due to the fact that in dual fuel operation there is proper fuel mixing and CNG has higher energy content than 


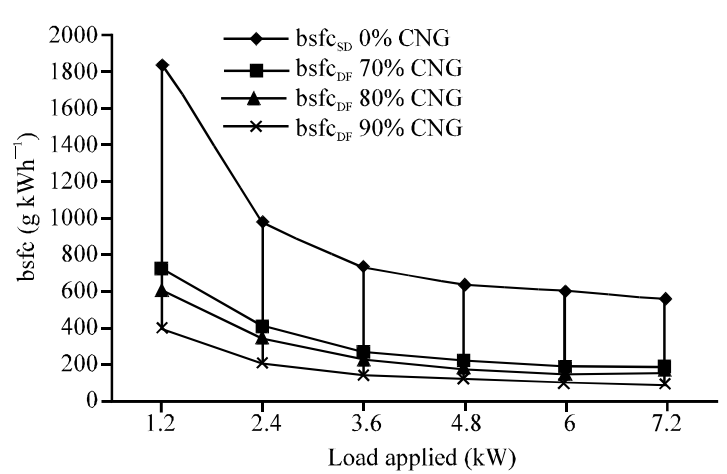

Fig. 7: Brake specific fuel consumption of straight diesel and dual fuel modes at CNG substitution rates of 70,80 and $90 \%$

diesel fuel. From Fig. 7, it is clear that bsfc of dual fuel engine is far less than that of pure diesel operation for both CNG rates of 70,80 and $90 \%$ from no load to $7.2 \mathrm{~kW}$ load. It is also clear that bsfc of dual fuel engine is the least for CNG rate of $90 \%$ under all load conditions. This decrease in bsfc of dual fuel engine is perhaps due to the improved combustion with high substitution rates of $\mathrm{CNG}$ under different load conditions.

Engine running cost analysis: The running cost of an engine is expressed in terms of fuel consumption cost for $01 \mathrm{~h}$ of continuous running the engine at a particular load. In the present analysis, the cost of diesel fuel has been assumed as Rs. $41.27 \mathrm{~L}^{-1}$ and that of $\mathrm{CNG}$ as Rs. $29.80 \mathrm{~kg}^{-1}$. This cost for straight diesel and dual fuel modes of operation of the engine is computed using the formulated equations 13-16 based on thermodynamic analysis and results are represented graphically:

$$
(\mathrm{RC})]_{\mathrm{gD}}=\mathrm{dfr} \times 60 \times(\mathrm{CP})_{\text {Dioul }}
$$

Where:

$\mathrm{RC}_{\mathrm{SD}} \quad=$ Engine running cost for straight diesel mode in Rs. $\mathrm{kWh}^{-1}$

dfr $=$ Diesel flow rate in $\mathrm{mL} \mathrm{min}{ }^{-1}$

$\mathrm{CP}_{\text {diesel }}=$ Cost Price of diesel in Rs. $\mathrm{L}^{-1}$

$$
(\mathrm{R} . \mathrm{C})_{\mathrm{Df}}=(\mathrm{R} . \mathrm{C})_{\mathrm{SD}}+(\mathrm{R} . \mathrm{C})_{\mathrm{CNG}}
$$

Where:

$\mathrm{RC}_{\mathrm{DF}}$ = Engine running cost for dual fuel mode in Rs. $\mathrm{KWh}^{-1}$

$\mathrm{RC}_{\mathrm{CNG}}=$ Running cost due to CNG fuel in Rs. $\mathrm{kWh}^{-1}$

$$
(\mathrm{RC})_{\mathrm{CNO}}=\frac{\left\{\mathrm{cfr} \times 3 \times([\mathrm{CP})]_{\mathrm{CNa}}\right\}}{50}
$$

Where:

cfr $\quad=$ CNG flow rate in $\mathrm{L} \mathrm{min}^{-1}$

$\mathrm{CP}_{\mathrm{CNG}}=$ Cost Price of CNG in Rs. $\mathrm{kg}^{-1}$

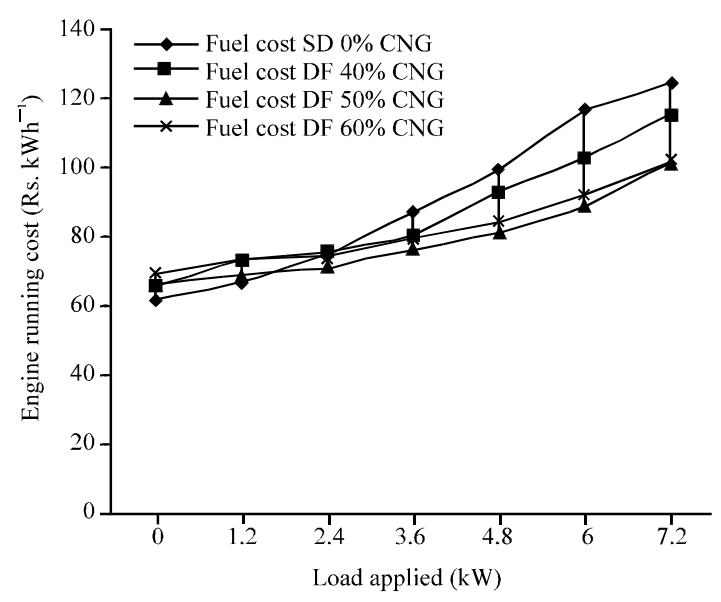

Fig. 8: Variation of engine running cost of straight diesel and dual fuel modes at CNG substitution rates of 40,50 and $60 \%$

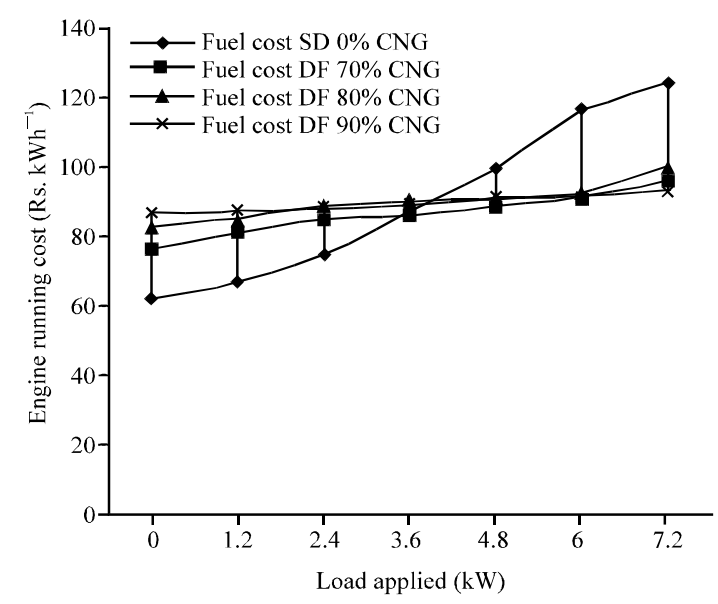

Fig. 9: Variation of engine running cost of straight diesel and dual fuel modes at CNG substitution rates of 70,80 and $90 \%$

$$
(\mathrm{R} . \mathrm{C})_{\mathrm{DF}}=\mathrm{dfr} \times 60(\mathrm{C} . \mathrm{P})_{\mathrm{Diesel}}+\frac{\left\{\mathrm{cfr} \times 3(\mathrm{C} . \mathrm{P})_{\mathrm{CNG}}\right\}}{50}
$$

where, the symbols used in Eq. 16 have been already used in Eq.13-15. From Fig. 8, it is clear that the engine running cost of dual fuel engine is more than that of straight diesel engine at low load conditions at CNG rates of 40,50 and $60 \%$. It decreases as the $\mathrm{CNG}$ rate is increased to $50 \%$ at a load of $2.4 \mathrm{~kW}$. Engine running cost of dual fuel engine is less than that of straight diesel from $2.4-7.2 \mathrm{~kW}$ engine load. This is due to replacement of costly diesel fuel with cheap CNG.

From Fig. 9, it is clear that running cost of dual fuel engine for CNG substitution rates of 70,80 and $90 \%$ is more than that of straight diesel mode up to $2.4 \mathrm{~kW}$ 
engine load. It is less than straight diesel mode for $\mathrm{CNG}$ rate of $70 \%$ at $3.6 \mathrm{~kW}$ load and for CNG rate of 80 and $90 \%$ at $4.8 \mathrm{~kW}$ engine load. The gap between the two costs is becomes much wide as the load on the engine is increased from $4.8 \mathrm{~kW}$ up to $7.2 \mathrm{~kW}$ load for $\mathrm{CNG}$ rate of 70 , 80 and $90 \%$. This reduction in running cost of dual fuel engine is due to many factors, the main among them are reduction of bsfc as the $\mathrm{CNG}$ substitution increases, lower cost of $\mathrm{CNG}$ than diesel fuel and higher calorific value for $\mathrm{CNG}$.

\section{CONCLUSION}

In the present study, firstly the conversion of a conventional multi-cylinder diesel engine in to dual fuel mode was successfully made possible by carrying out minor modifications and secondly all the experiments were conducted successfully. On the basis of experimental investigations on utilization of $\mathrm{CNG}$ in a converted diesel engine the following salient results have been drawn:

- A CNG-Air venturi mixer has been designed and fabricated for the twin cylinder CNG-diesel dual fuel stationary engine using Engineering Equation Solver Software. This study shows that conversion of a conventional diesel engine to CNG-diesel dual fuel engine can be achieved with minimum possible modifications

- At low loads brake thermal efficiency in dual fuel mode is inferior to straight diesel mode but as the load was increased beyond low load brake thermal efficiency for dual fuel engine improved significantly with increase in CNG substitution rates. At higher engine loads dual fuel mode efficiency is more than that of straight diesel mode for all the $\mathrm{CNG}$ substitution rates and is suggested that at low loads low percentage of $\mathrm{CNG}$ in the range of $10-20 \%$ can be used as the load is further increased, CNG substitution rate should be increased substantially

- Brake thermal efficiency of dual fuel engine at a load of $7.2 \mathrm{~kW}$ is more than pure diesel engine by $7.14 \%$ for 50,60 and $7.21 \%$ for $90 \% \mathrm{CNG}, 9.05 \%$ for $70 \%$ $\mathrm{CNG}, 2.24 \%$ for $80 \% \mathrm{CNG}$ rates whereas it is lower than straight diesel mode by $2.85 \%$ for $40 \%$ CNG rate. This indicates that CNG substitution should be commenced with rate of $10-20 \%$ and after this it should be substituted at a faster rate in order to get better thermal efficiency of dual fuel engine at medium to high engine loads
- It is further observed that bsfc of a dual fuel engine is far less than that of pure diesel engine at all engine loads and for all the CNG substitution rates and it becomes minimum at about $6.0 \mathrm{~kW}$ engine load for dual mode. This better bsfc in case of dual fuel mode is on account of higher energy content of CNG fuel than diesel and full potential of CNG is utilized in the converted diesel engine

- Running cost of dual fuel engine is much less than that of straight diesel mode at all engine loads and all CNG substitution rates. The gap between the two costs increases from $2.4 \mathrm{~kW}$ engine load and this is maximum at $7.2 \mathrm{~kW}$ load for CNG substitution rates from $60-90 \%$

- In the present experimental research saving in consumption of conventional diesel fuel is achieved to the tune of $90 \%$ by its replacement with cheap CNG fuel. This implies that only $10 \%$ diesel fuel and $90 \% \mathrm{CNG}$ fuel were used to operate the converted diesel engine in dual fuel mode. Hence, a great saving in the conventional source of energy, i.e., diesel fuel which is depleting at a faster rate than petrol can be achieved by its replacement with cheap, abundantly available and environmentally friendly CNG fuel

- This research is being extended further and is presently under progress towards measurement and analysis of exhaust emissions from CNG-diesel dual fuel engine, computer simulation of CNG-diesel dual fuel cycle and validation of simulation data with experimental data

Therefore from the above positive merits, it can be founded that compressed natural gas seems a promising alternative fuel and has full potential to replace the conventional diesel fuel by using it in dual fuel mode of operation in existing diesel engines with minor modifications.

\section{REFERENCES}

Ahmad, N., M.K. Gaiendra Babu and A. Ramesh, 2005. Experimental investigations of different parameters affecting the performance of a CNG-Diesel dual fuel engine. SAE Paper No. 2005-01-3767. http://papers. sae.org/2005-01-3767/.

Arora, K.R., 2010. Fluid Mechanics, Hydraulics and Hydraulic Machines. Standard Publishers Distributor, New Delhi.

Corbo, P., M. Gambino, S. Iannaccone and A. Unich, 1995. Comparison between lean-burn and stoichiometric technologies for CNG heavy-duty engines. $\mathrm{SAE}$ Ineternational, Technical Papers, No. 950057, http://papers.sae.org/950057/. 
Doughty, G.E., S.R. Bell and K.C. Midkiff, 1992. Natural gas fueling of a caterpillar 3406 diesel engine. J. Eng. Gas Turbines Power, 114: 459-465.

Egusquiza, J.C., S.L. Braga and C.V.M. Braga, 2009. Performance and gaseous emissions characteristics of a natural gas/diesel dual fuel turbocharged and aftercooled engine. J. Braz. Soc. Mech. Sci. Eng., 31: $142-150$.

Hountalas, D.T. and R.G. Papagiannakis, 2000. Development of a simulation model for direct injection dual fuel diesel-NG engines. SAE Technical Paper 2000-01-0286.

Karim, G.A., 1983. The dual fuel engine of the compression ignition type - prospects, problems and solutions: A review. SAE Inernational, Technical Papers, No. 831073. http://papers.sae.org/831073/.

Karim, G.A., 1991. An examination of some measures for improving the performance of gas fuelled diesel engines at light load. SAE Inernational, Technical Papers, Paper Number: 91 2366, DOI: 10.4271/912366, http://papers.sae. org/912366/.

Kirti, B., B. Akhil, S. Anuradha and K. Mukesh, 2005. Performance and emissions of natural gas fueled internal combustion engine: A review. J. Sci. Ind. Res., 64: 333-338.
Kusaka, J., K. Tsuzuki, Y. Daisho and T. Saito, 2002. A numerical study on combustion and exhaust gas emissions characteristics of a dual fuel natural gas engine using a multi-dimensional model combined with detailed kinetics. Engine Modeling Techniques: SI and Diesel, SAE International, Technical Paper. http://subscriptions. sae.org/content/2002-01-1750/.

Li, L.P., 2004. The effect of compression ratio on the CNGdiesel engine. A Research Project. University of Southern Queensland. http://eprints.usq.edu.au/72/1/ LIMPeiLi-2004.pdf.

Maji, S., 2002. A Study of alternative fuels in S.I. engines for fuel efficiency and exhaust emission control. Ph.D. Thesis, University of Delhi, India.

Saraf, R.R., S.S. Thipse and P.K. Saxena, 2008. Diesel-CNG dual fuel technology: A viable alternate energy source. Proceedings of the 15th ISME International Conference on New Horizons of Mechanical Engineering, March 18-30, 2008, Bhopal, India.

Singh, S., S.C. Kong, R.D. Reitz, S.R. Krishnan and K.C. Midkiff, 2004. Modeling and experiments of dual-fuel engine combustion and emissions. SAE Trans., 113: 124-133.

Song, S. and P.G. Hill, 1985. Dual-fueling of a prechamber diesel engine with natural gas. J. Eng. Gas Turbines Power, Vol. 107. 10.1115/1.3239836. 